\title{
Assessment of Heavy Metal Concentration in Tissues of Three Owl Species From Visakhapatnam, India
}

\author{
Sanchari Biswas ${ }^{*} \dagger$, Ch Ramakrishna* and Y A Maruthi** \\ *Department of Environmental Science, GITAM (Deemed to be University), Visakhapatnam-530045, Andhra Pradesh, India \\ **Department of Biotechnology and Bio Sciences, Krishna University, Machilipatnam-521001, Andhra Pradesh, India \\ $\dagger$ Corresponding author: Sanchari Biswas; biswasanchari@gmail.com
}

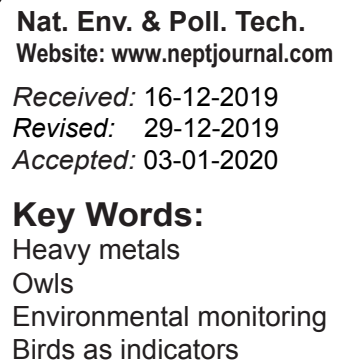

\begin{abstract}
The occurrence of heavy metals into the environment through various natural and anthropogenic sources is inevitable due to their persistent nature. This study investigated the concentration of heavy metals lead $(\mathrm{Pb})$, zinc $(\mathrm{Zn})$ and chromium $(\mathrm{Cr})$ in liver, kidney, muscle and bones of three different species of owls namely Indian Eagle Owl (Bubo bengalensis), Barn Owl (Tyto alba) and Spotted Owlet (Athene brama) from Visakhapatnam, Andhra Pradesh, India. Given their sentinel role, birds can be used as suitable and reliable indicators in monitoring the quality of the environment. From the study, it was observed that Bubo bengalensis accumulated the highest concentration of metals followed by Athene brama and Tyto alba. On an average, the concentration of $\mathrm{Zn}(1.67 \pm 1.40 \mu \mathrm{g} / \mathrm{g})$ was higher than $\mathrm{Pb}(0.079 \pm 0.05 \mu \mathrm{g} / \mathrm{g})$ and $\mathrm{Cr}(0.99 \pm 1.11 \mu \mathrm{g} / \mathrm{g})$. Among all the species, Spotted Owlet (Athene brama) recorded the highest concentration of $\mathrm{Zn}$ in bone $(3.98 \mu \mathrm{g} / \mathrm{g})$ whereas in the bone of Indian Eagle Owl (Bubo bengalensis) $2.44 \mu \mathrm{g} / \mathrm{g}$ of chromium ( $\mathrm{Cr}$ ) was reported. Pearson's correlation of the data showed significant positive correlations in the absorption of metals by the tissues. Kruskal-Wallis ANOVA was applied to validate the results and check whether the groups originated from the same population. Additionally, Principle Component Analysis (PCA) revealed that $\mathrm{Pb}$ showed a strong relationship with both $\mathrm{Zn}$ and $\mathrm{Cr}$ and might be due to the differences of sources of these elements in the environment.
\end{abstract}

\section{INTRODUCTION}

Over the past few years, heavy metals have been accumulating in our environment due to the various anthropogenic point and non-point sources. Heavy metals are persistent and tend to accumulate in living forms. In some cases, heavy metals can change into a more toxic form through biochemical processes (Grúz et al. 2018). Due to the biomagnification properties of certain elements like organic forms of arsenic and mercury, when they get biomagnified over the foodchain, they jeopardize the health of living forms (De Luca et al. 2001, Grúz et al. 2018). It was reported by Denneman \& Douben (1993) that birds were first used for monitoring the environmental conditions in the early 1960 s because birds are more susceptible and tend to react to environmental changes. Battaglia et al. (2005) reported that using sentinel species aids in producing significant data to monitor environmental quality. They also stated that the prolonged exposure to the contaminants in certain species is due to their biological habits which if analysed would generate relevant data apart from that originating from water and soil. Tertiary consumers are good indicators in determining the extent of environmental contamination in the ecosystem across the food web (Sanchari et al. 2016, Biswas et al. 2019). It stated that birds have been used as bioindicators for monitoring environmental pollutants (Gragnaniello et al. 2001, Muralidharan et al. 2004) specifically heavy metals (Mochizuki et al. 2002) since they are easy to access, broadly distributed in ecosystems, sensitive to toxins and on higher trophic level of food chains. Guitart et al. (2010) concluded that when compared to wild animals, wild birds like waterfowl and raptors were the victims of poisoning. Additionally, apart from buzzards, little owls (Battaglia et al. 2005) and Indian Eagle Owls, which feed on a wide range of prey, can provide sufficient information regarding biomonitoring of the environment (Kim \& Koo 2007). Different birds including Eagle Owls have been frequently used as biomonitors to monitor heavy metal burden in the environment (Nighat et al. 2013, Guitart et al. 2010, Grúz et al. 2018).

Heavy metals can accumulate in different tissues including liver, kidney and feathers of the birds (Deng et al. 2007, Jayakumar \& Muralidharan 2011, Biswas et al. 2019). Birds can excrete metals via different routes like feathers and excreta (Furness 1996, Boncompagni et al. 2003, Mustafa et al. 2015) or into eggs (Burger et al. 1993, Grúz et al. 2018). Studies by various authors suggest that heavy metals influence reproductive health of some birds (Janssen et al. 
2003, Dauwe et al. 2004) increased chances of diseases and increased reproductive failure (Furness 1996) and shifts in behaviour patterns. Therefore, monitoring of heavy metals in the environment not only provides species-specific information but can also aid in providing area-specific information about the changes in contaminant levels in the environment (Jayakumar \& Muralidharan 2011). Studies done in the Indian context are limited. However, some of the studies carried out have recorded important levels of metals from various areas in southern and northern India (Jayakumar \& Muralidharan 2011, Kaur et al. 2014, Sharma \& Vashishat 2017, Gaba \& Vashishat 2018, Manjula et al. 2015, Biswas et al. 2019). Visakhapatnam, Andhra Pradesh, India is home to diversified avifauna but is presently facing the consequences of development and urbanisation. Owls belong to the Strigidae family and are regarded as birds of prey which usually prey on rodents or small mammals. Due to their foraging habits, owls can fly up to long distances to search for food. The present study was carried out to investigate the concentration of certain heavy metals in three species of owls and establish some data because studies done in the region remain limited.

\section{MATERIALS AND METHODS}

Study area and sampling: In India, owls are protected species under The Wildlife Protection Act 1972 (Schedule IV). As per bioethical concerns, domesticating or killing of any protected species is a strictly punishable offence. Hence, the present study involved the collection of dead birds (Owls) as reported by locals from residential areas and opportunistic findings of electrocution kill. Visakhapatnam is a situated along the Eastern Ghats which hosts a variety of flora and fauna. At the same time, it is also a fast-growing hub, budding with development and urbanization. A total of 27 samples including adults, sub-adults and juveniles were collected from Simhachalam, $\left(17.7664^{\circ} \mathrm{N}, 83.2508^{\circ} \mathrm{E}\right)$, Kambalakonda $\left(17.7664^{\circ} \mathrm{N}, 83.3496^{\circ} \mathrm{E}\right)$ and old post office or port area, $\left(17.6940^{\circ} \mathrm{N}, 83.2922^{\circ} \mathrm{E}\right)$ on an opportunistic basis represented in Fig. 1. The samples collected were transported to the lab in ice box.

Necropsy of specimens: The samples were removed from ice storage and thawed for an hour. Necropsy of all samples were carried out individually. Birds (owls) in which rigor mortis had set in were also considered for post-mortem. The specimen was placed on the post mortem tray in the dorsal position and external observations were made in order to find discharges from mouth and cloaca if any. The breast feathers were plucked gently in order to reveal the epidermis where incision lines were made with scalpel and the breast tissue was cut open. On reaching the sternum, the abdominal tissue was further cut to reveal the visceral contents. Observations were carried out to check clots, exudate and fluids. The liver and pair of kidneys were procured after removing them with help of forceps and scissors. A small amount of breast tissue was also removed from the bird. The femur bone was cut with the help of stout scissor and all the contents were wrapped in aluminium foil, labelled respectively and stored in deep freezer at $-20^{\circ} \mathrm{C}$ for the next experimental procedures.

Apparatus and reagent: All the laboratory apparatus used in the experiment were cleansed with Millipore Sigma ex$\operatorname{tran}{ }^{\circledR}$ MA 03 solution to decontaminate them. All chemicals and reagents used in the present study were of Merck grade which included nitric acid, $\mathrm{HNO}_{3}(69 \%$ Emplura Merck), perchloric acid, $\mathrm{HClO}_{4}(60 \%$ Emparta ACS) and hydrogen peroxide $\mathrm{H}_{2} \mathrm{O}_{2}$ (30\% Emplura Merck).

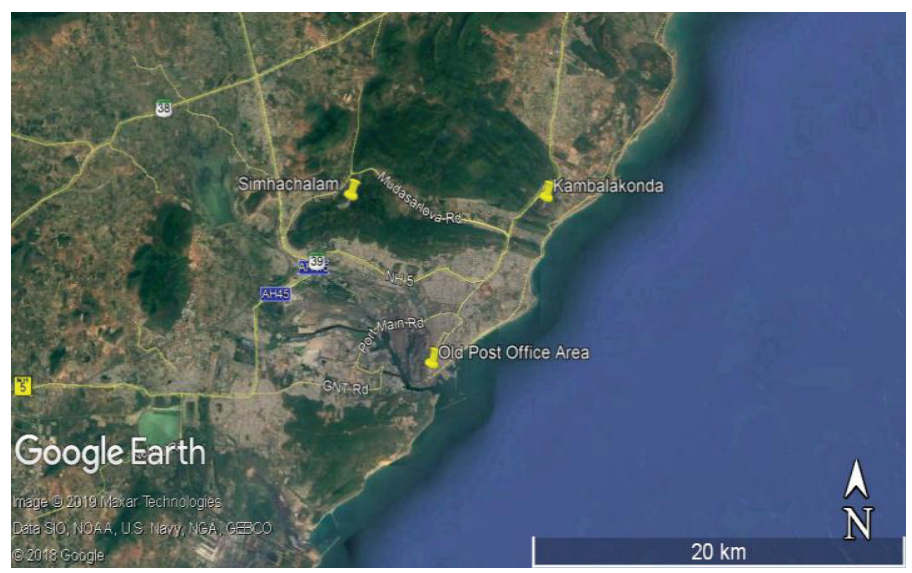

Fig. 1: Map showing sampling points and study area (source: https://earth.google.com/web) 
Acid digestion procedure: All tissues were thawed initially and then oven-dried at $80^{\circ} \mathrm{C}$ for 24 hours. With the help of mortar and pestle, each tissue was then powdered. The acid digestion process was initiated by following the procedure suggested by Muralidharan et al. (2004). After weighing, 1-5 $\mathrm{g}$ of powdered sample was transferred to Teflon beakers to which $10 \mathrm{~mL} \mathrm{HNO}_{3}$ was added slowly. The mixture was then placed on a hot plate and heated for about $30 \mathrm{~min}$ until a thin solution was obtained. This was followed by pipetting $5 \mathrm{~mL}$ of $\mathrm{HClO}_{4}$. The mixture was further heated for 15 mins until the solution turned clear. After cooling the solution, finally $2 \mathrm{~mL}$ of $\mathrm{H}_{2} \mathrm{O}_{2}$ was added and reheated till a final transparent solution was obtained. The Hydrogen peroxide $\left(\mathrm{H}_{2} \mathrm{O}_{2}\right)$ was added to result in digestion of excessive organic matter present if any. All samples were finally digested and filtered using Whatman No. 1 filter paper. Millipore water (18.2 Ohms, Elga PURE Waterlab) was used to fill up the volume till $25 \mathrm{~mL}$. All solutions obtained were stored in pre-cleaned polythene vials and refrigerated for analysis.

Analysis of heavy metals: The Inductively Coupled Plasma Mass Spectrometry (ICPMS), Agilent 770s, Agilent Technologies, Japan was employed to analyse heavy metals namely $\mathrm{Pb}, \mathrm{Zn}$ and $\mathrm{Cr}$. Calibration standards manufactured by NIST
(National Institute of Standard Technology), U.S were used for calibration of each metal. The standards of the elements $(\mathrm{Pb}$, $\mathrm{Zn}, \mathrm{Cr}$ ) were prepared according to $0.5 \mathrm{ppb}, 1 \mathrm{ppb}, 5 \mathrm{ppb}, 10$ ppb, $25 \mathrm{ppb}, 50 \mathrm{ppb}, 100 \mathrm{ppb}$ respectively. To obtain accuracy in results, the samples were run in triplicates and mean $( \pm \mathrm{SD})$ was considered. The results obtained were expressed in $\mathrm{ppm}(\mu \mathrm{g} / \mathrm{g})$.

\section{RESULTS}

Opportunistically, a total of 27 Owls were collected from Simhachalam, Kambalakonda and Old post Office (Port Area) which are represented in Table 1 along with their current conservation status according to IUCN (2019). Heavy metal concentrations of $\mathrm{Pb}, \mathrm{Zn}$ and $\mathrm{Cr}$ were determined and the results have been expressed in dry weight (because dry weight values are more consistent compared to wet weight) (Adrian \& Steven 1979, Biswas et al. 2019). Metal concentrations differed among various tissue of birds and among the species which are represented in Table 2 and Fig. 2 respectively. Among all the species studied, Indian Eagle Owl (Bubo bengalensis) was recorded to have the highest metal content $(1.33 \pm 1.10 \mu \mathrm{g} / \mathrm{g})$ followed by Spotted Owlet (Athene brama) $(1.21 \pm 1.63 \mu \mathrm{g} / \mathrm{g})$ and Barn Owl (Tyto alba) $(0.19 \pm 0.15 \mu \mathrm{g} / \mathrm{g})$ as represented in Fig. 3 and Fig. 4.

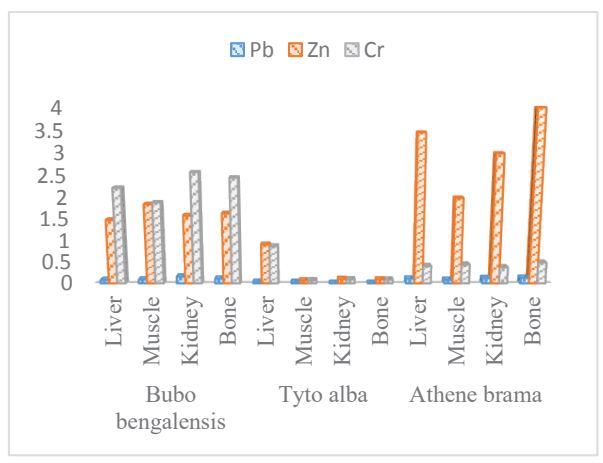

Fig. 2: Concentration of all metals (expressed in $\mu \mathrm{g} / \mathrm{g}$ ) in various tissues of owls.

Table 1: Sampling locations of owls and their current population trend (IUCN 2019).

\begin{tabular}{|c|c|c|c|c|}
\hline $\begin{array}{l}\text { Common } \\
\text { Name }\end{array}$ & Scientific Name & $\begin{array}{l}\text { Sampling } \\
\text { Area \& GPS } \\
\text { Location }\end{array}$ & $\begin{array}{l}\text { Sample } \\
\text { Size }\end{array}$ & $\begin{array}{l}\text { Population Trend, } \\
\text { IUCN } 2019\end{array}$ \\
\hline $\begin{array}{l}\text { Indian } \\
\text { Eagle Owl }\end{array}$ & Bubo bengalensis & $\begin{array}{l}\text { Simhachalam } \\
17.7664^{\circ} \mathrm{N}, 83.2508^{\circ} \mathrm{E}\end{array}$ & 7 & Stable \\
\hline $\begin{array}{l}\text { Barn } \\
\text { Owl }\end{array}$ & Tyto alba & $\begin{array}{l}\text { Old Post } \\
\text { Office (Port area) } \\
17.6940^{\circ} \mathrm{N}, 83.2922^{\circ} \mathrm{E}\end{array}$ & 9 & Stable \\
\hline $\begin{array}{l}\text { Spotted } \\
\text { Owlet }\end{array}$ & Athene brama & $\begin{array}{l}\text { Kambalakonda } \\
17.7664^{\circ} \mathrm{N}, 83.3496^{\circ} \mathrm{E}\end{array}$ & 11 & Stable \\
\hline
\end{tabular}


The accumulation of metals in organs followed the order muscle $>$ kidney $>$ bone $>$ liver which are represented in Fig. 5. Within metals, $\mathrm{Zn}$ was reported to be the highest $(1.67 \pm 1.40$ $\mu \mathrm{g} / \mathrm{g})$ compared to $\mathrm{Cr}(0.99 \pm 1.11 \mu \mathrm{g} / \mathrm{g})$ and $\mathrm{Pb}(0.58 \pm 0.05$ $\mu \mathrm{g} / \mathrm{g}$ ) which are represented in Fig. 6. Between species, the accumulation of metals by the organs was highest in Bubo bengalensis followed by Athene brama and Tyto alba.

Statistical analysis: In the PCA analysis, 3 PCAs for 3 different species were computed, and the variances explained by them were $67.35 \%, 97.83 \%$ and $100 \%$ for Athene brama (Table 3) respectively, $85.77 \%, 100 \%$ and $100 \%$ in Tyto alba (Table 4) followed by Bubo bengalensis as $68.66 \%, 97.53 \%$ and $100 \%$ (Table 5). In Tyto alba, Cr falls in component I,

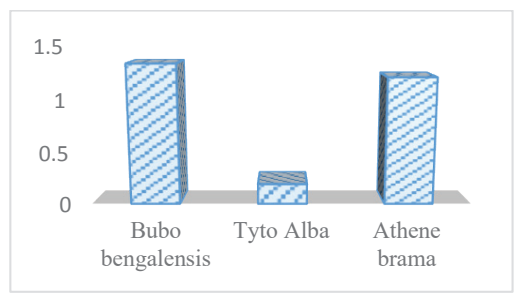

Fig. 3: Metal accumulation among species.

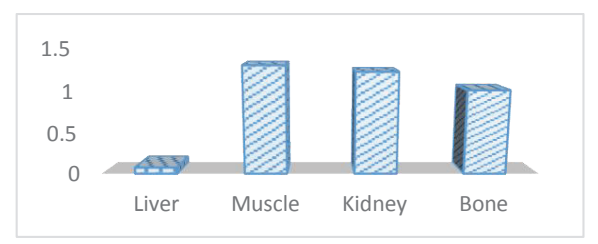

Fig. 5: Mean metal accumulation by organs (concentration expressed in $\mu \mathrm{g} / \mathrm{g})$.
$\mathrm{Zn}$ and $\mathrm{Pb}$ showed a strong relationship and falls in component II. Whereas in Bubo bengalensis, $\mathrm{Pb}$ and $\mathrm{Cr}$ showed a strong relationship which falls under component I. $\mathrm{Zn}$ does not show any relationship with remaining metals and falls under Component IV. In Athene brama, it was observed that $\mathrm{Cr}$ did not show any relationship with the other heavy metals and falls under component $\mathrm{I}$, and $\mathrm{Zn}$ and $\mathrm{Pb}$ show a strong relationship and falls under Component II.

Pearson's Correlation Coefficient (r) analysis was conducted in order to understand the relation between two variables namely organs (tissues) and metals accumulated by them. Significant positive correlations were obtained between the metals and organs (Table 6; Table 7; Table 8)

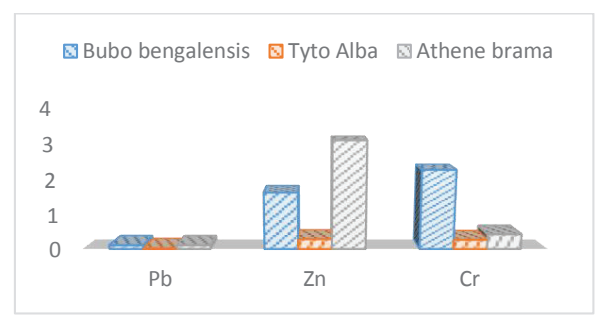

Fig. 4: Mean concentrations of all metals expressed in $\mu \mathrm{g} / \mathrm{g}$.

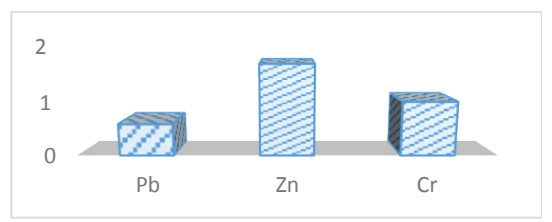

Fig. 6: Mean metal concentration (expressed in $\mu \mathrm{g} / \mathrm{g}$ ).

Table 2: Concentration of heavy metals in different organs of Bubo bengalensis, Tyto alba and Athene brama (expressed in $\mu \mathrm{g} / \mathrm{g}$ ).

\begin{tabular}{|c|c|c|c|c|}
\hline Bird & Organs & $\mathrm{Zn}$ & $\mathrm{Cr}$ & $\mathrm{Pb}$ \\
\hline \multirow[t]{4}{*}{ Indian Eagle Owl (Bubo bengalensis) } & Muscle & $1.84 \pm 0.87$ & $1.88 \pm 0.95$ & $0.09 \pm 0.03$ \\
\hline & Liver & $1.48 \pm 1.32$ & $2.21 \pm 0.93$ & $0.08 \pm 0.03$ \\
\hline & Kidney & 1.58 & $2.56 \pm 1.34$ & $0.16 \pm 0.07$ \\
\hline & Bone & $1.63 \pm 1.44$ & $2.44 \pm 1.25$ & $0.11 \pm 0.06$ \\
\hline \multirow[t]{4}{*}{ Barn Owl (Tyto alba) } & Muscle & $0.068 \pm 0.87$ & $0.071 \pm 0.95$ & $0.029 \pm 0.03$ \\
\hline & Liver & $0.91 \pm 1.32$ & $0.87 \pm 0.93$ & $0.034 \pm 0.03$ \\
\hline & Kidney & $0.098 \pm 1.44$ & $0.092 \pm 1.34$ & $0.008 \pm 0.07$ \\
\hline & Bone & $0.089 \pm 1.95$ & $0.086 \pm 1.25$ & $0.007 \pm 0.06$ \\
\hline \multirow[t]{4}{*}{ Spotted Owlet (Athene brama) } & Muscle & $1.98 \pm 0.87$ & 0.440 .95 & $0.08 \pm 0.03$ \\
\hline & Liver & $3.44 \pm 1.32$ & $0.41 \pm 0.93$ & $0.11 \pm 0.03$ \\
\hline & Kidney & $2.98 \pm 1.44$ & $0.38 \pm 1.34$ & $0.12 \pm 0.07$ \\
\hline & Bone & $3.98 \pm 1.95$ & $0.49 \pm 1.25$ & $0.13 \pm 0.06$ \\
\hline
\end{tabular}


Table 3: Explanation for the variation of elements in Spotted Owlet (Athene brama).

\begin{tabular}{|lll|}
\hline Component & $\begin{array}{l}\text { Variance } \\
\%\end{array}$ & $\begin{array}{l}\text { Cumulative } \\
\%\end{array}$ \\
\hline 1 & $67.35 \%$ & $67.35 \%$ \\
2 & $30.47 \%$ & $97.83 \%$ \\
3 & $2.17 \%$ & $100.00 \%$ \\
\hline
\end{tabular}

respectively. In case of Lead, significant positive correlations were observed between muscle and kidney, $(\mathrm{r}=0.99)$, muscle and bone $(\mathrm{r}=0.98)$, and kidney and bone $(\mathrm{r}=0.98)$. For Zinc, significant positive correlations were obtained between liver and kidney ( $\mathrm{r}=0.94)$, liver and bone $(\mathrm{r}=0.98)$, muscle and kidney $(\mathrm{r}=0.90)$, muscle and bone $(\mathrm{r}=0.83)$ and kidney and bone $(r=0.99)$. In case of Chromium, significant positive correlations were obtained between liver and kidney (0.90), liver and bone (0.93), muscle and kidney (0.91), muscle and bone (0.99), kidney and bone (0.99) and where $\mathrm{p}<0.05$ suggests that kidney and liver are the organs where most of the metals were absorbed. According to Kirubhanandhini et al. (2019), liver and kidney are good indicators for providing us with data about the metal contaminated environment.

To check the level of metal contamination among the tissues of various species in the present study, Kruskal-Wallis Test and Principal Component Analysis (PCA) using Origin Lab 2019 were conducted to understand the differences of metal accumulation among the 3 different species. The Kruskal-Wallis test was used to determine whether three or more independent samples originate from the same population and is a nonparametric test. When significant test results are obtained, it means that at least one sample differs from another. The p-value for Indian Eagle Owl (Bubo bengalensis) was 0.91 and for Spotted Owlet (Athene brama) was 0.86

Table 5: Explanation for the variation of elements in Indian Eagle Owl (Bubo bengalensis).

\begin{tabular}{|lll|}
\hline Component & $\begin{array}{l}\text { Variance } \\
\%\end{array}$ & $\begin{array}{l}\text { Cumulative } \\
\%\end{array}$ \\
\hline 1 & $68.66 \%$ & $68.66 \%$ \\
2 & $28.87 \%$ & $97.53 \%$ \\
3 & $2.47 \%$ & $100.00 \%$ \\
\hline
\end{tabular}

Table 7: Correlation among the different organs for zinc ( $\mathrm{Zn}), \mathrm{p}<0.05$.

\begin{tabular}{|lllll|}
\hline & Liver & Muscle & Kidney & Bone \\
\hline Liver & 1 & & & \\
Muscle & 0.721359 & 1 & & \\
Kidney & 0.948101 & 0.904135 & 1 & \\
Bone & 0.982437 & 0.837917 & 0.990781 & 1 \\
\hline
\end{tabular}

Table 4: Explanation for the variation of elements in Barn Owl (Tyto alba).

\begin{tabular}{|lll|}
\hline Component & $\begin{array}{l}\text { Variance } \\
\%\end{array}$ & $\begin{array}{l}\text { Cumulative } \\
\%\end{array}$ \\
\hline 1 & $85.77 \%$ & $85.77 \%$ \\
2 & $14.22 \%$ & $100.00 \%$ \\
3 & $0.00 \%$ & $100.00 \%$ \\
\hline
\end{tabular}

which confirmed that groups are not significantly different (Fig. 7, Fig. 8). The p-value was 0.45 for Barn Owl (Tyto alba) which confirmed that groups are significantly different (Fig. 9). The graphical form of Principal Component Analysis (PCA) obtained for three different Owl species are also represented in Fig.10, Fig.11 and Fig.12.

\section{DISCUSSION}

Zinc: Being the $23^{\text {rd }}$ abundant element found naturally on Earth's crust, zinc is naturally found in soils and sediments (Ullah et al. 2014). Zinc is an essential element required in the human body for growth and protection from renal toxicosis (Malik \& Zeb 2009, Grúz et al. 2018). Zn also plays a role in the activation of enzymes and gene regulation expression but higher levels of zinc can impart physiological changes leading to decline in the population of birds (Gaba \& Vashishat 2018, Kushwaha 2016). Zinc mobility into the environment is from manmade as well as natural sources (Ullah et al. 2014, Mustafa et al. 2015).

The average concentration of $\mathrm{Zn}$ when compared to other metals in the study was found to be highest $1.67 \mu \mathrm{g} / \mathrm{g}$ and Spotted Owlet (Athene brama) recorded the maximum accumulation of $\mathrm{Zn}$ content in bone $(3.98 \mu \mathrm{g} / \mathrm{g})$ followed by liver $(3.44 \mu \mathrm{g} / \mathrm{g})$, kidney $(2.98 \mu \mathrm{g} / \mathrm{g})$ and muscle $(1.98 \mu \mathrm{g} / \mathrm{g})$ when compared to Barn Owl and Indian Eagle Owl. Indian

Table 6: Correlation among the different organs for lead $(\mathrm{Pb}), \mathrm{p}<0.05$.

\begin{tabular}{|lllll|}
\hline & Liver & Muscle & Kidney & Bone \\
\hline Liver & 1 & & & \\
Muscle & 0.135324 & 1 & & \\
Kidney & 0.113724 & 0.999763 & 1 & \\
Bone & 0.278397 & 0.989305 & 0.985895 & 1 \\
\hline
\end{tabular}

Table 8: Correlation among the different organs for chromium $(\mathrm{Cr}), \mathrm{p}<0.05$.

\begin{tabular}{|lllll|}
\hline & Liver & Muscle & Kidney & Bone \\
\hline Liver & 1 & & & \\
Muscle & 0.903585 & 1 & & \\
Kidney & 0.937505 & 0.99619 & 1 & \\
Bone & 0.917254 & 0.999453 & 0.998528 & 1 \\
\hline
\end{tabular}




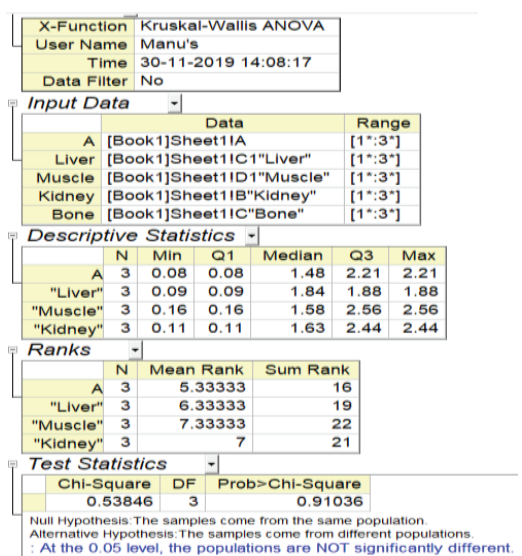

Fig. 7: Kruskal-Walis ANOVA of Indian Eagle Owl (Bubo bengalensis).

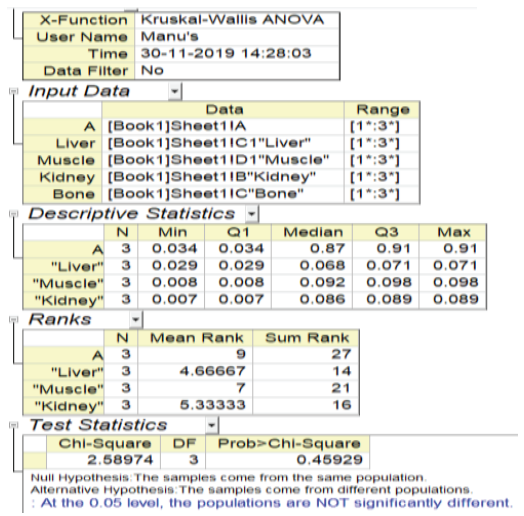

Fig. 9: Kruskal-Walis ANOVA of Barn Owl (Tyto alba).

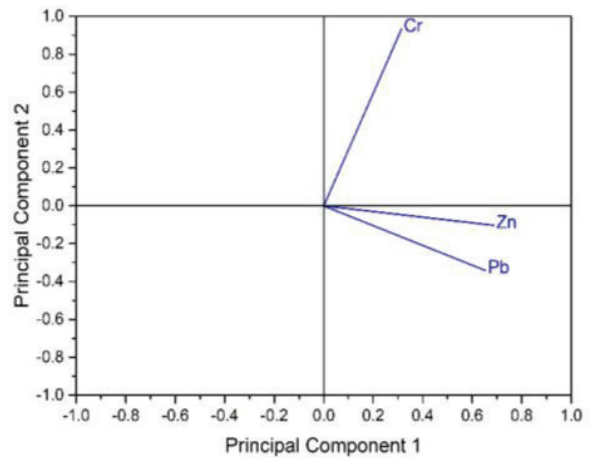

Fig. 11: Principal Component Analysis (PCA) of metals in Spotted Owlet (Athene brama).

Eagle Owl (Bubo bengalensis) recorded higher Zn content in the muscle $(1.84 \mu \mathrm{g} / \mathrm{g})$ followed by bone $(1.63 \mu \mathrm{g} / \mathrm{g})$, kidney $(1.58 \mu \mathrm{g} / \mathrm{g})$ and liver $(1.48 \mu \mathrm{g} / \mathrm{g})$. Compared to these two species of owls, Barn Owl (Tyto alba) recorded the lowest

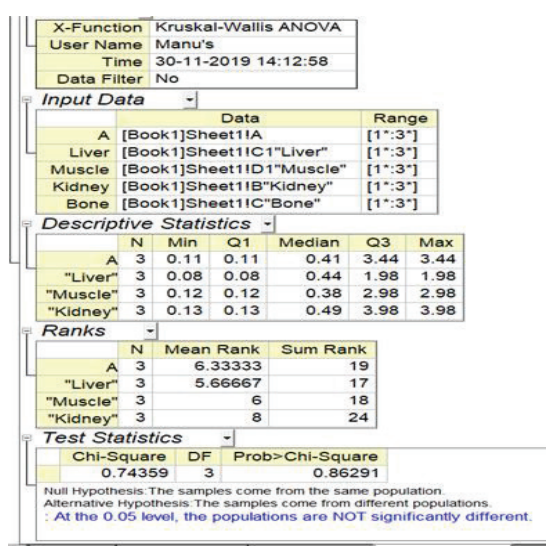

Fig. 8: Kruskal-Walis ANOVA of Spotted Owlet (Athene brama).

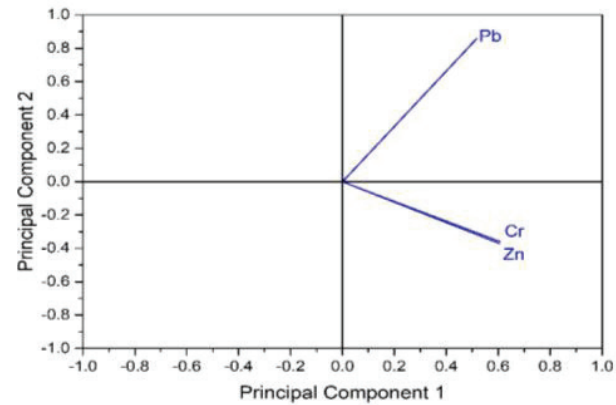

Fig. 10: Principal Component Analysis (PCA) of metals in Barn Owl (Tyto alba).

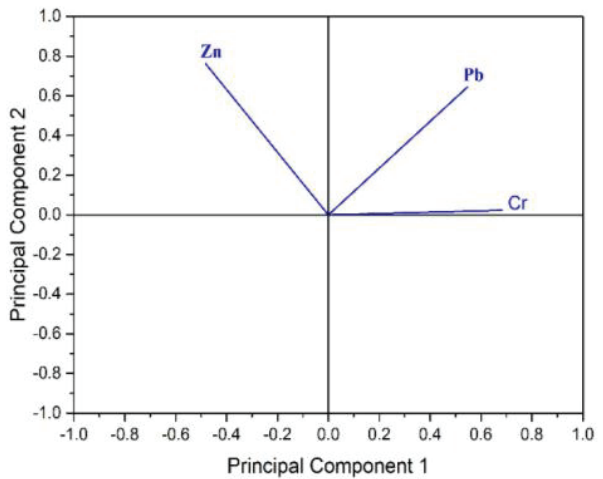

Fig. 12: Principal Component Analysis (PCA) of metals in Indian Eagle Owl (Bubo bengalensis).

Zn levels (0.91-0.068 $\mu \mathrm{g} / \mathrm{g})$ in its organs. In India, studies done on same species of birds namely Barn Owl and Spotted Owlet by Gaba \& Vashishat (2018) in Punjab yielded much higher concentrations of $\mathrm{Zn}(189.33-48.83 \mu \mathrm{g} / \mathrm{g})$ in excreta 
samples of Spotted Owlet, and 111.07 $\mu \mathrm{g} / \mathrm{g}$ (Zn) in Barn Owl. Denneman \& Douben (1993) reported a much higher level of $\mathrm{Zn}(535 \mu \mathrm{g} / \mathrm{g})$ in feathers of Barn Owls from the Netherlands whereas (Grúz et al. 2018) reported 157.21-110.64 $\mu \mathrm{g} / \mathrm{g}$ of $\mathrm{Zn}$ in owls from Hungary. A study done in Korea (Kim \& Koo 2007) recorded $120 \mu \mathrm{g} / \mathrm{g}$ of $\mathrm{Zn}$ in Indian Eagle Owl, $225 \mu \mathrm{g} / \mathrm{g}$ Zn in Brown Hawk Owl and $66.4 \mu \mathrm{g} / \mathrm{g}$ in Collared Scoops Owl. A study done in Punjab province of Pakistan by Nighat et al. (2013) detected $90.74 \mu \mathrm{g} / \mathrm{g}$ of $\mathrm{Zn}$ in Spotted Owlet feathers whereas, in case of Indian Eagle Owl, no Zn content was detected. The present study was in agreement with the findings of Mustafa et al. (2015) who reported 1.10$13.26 \mu \mathrm{g} / \mathrm{g}$ of $\mathrm{Zn}$ in Black Kite (Milvus migrans) tissues from Sargodha district, Punjab, Pakistan. Black Kites belong to the Family Accripiridae and also falls under birds of prey or raptors which make them similar to Owls in feeding habits.

Chromium: Chromium is a trace element and an essential microelement for animals (Kirubhanandhini et al. 2019), but tissue concentration exceeding $4 \mu \mathrm{g} / \mathrm{g}$ dry weight is a warning for growing contamination (Outridge \& Scheuhammer 1993, Boncompagni et al. 2003). Usually, $\mathrm{Cr}$ enters the body of the birds by nutrition (Grúz et al. 2018). Studies by various workers have reported that concentration of $\mathrm{Cr}$ more than $2.80 \mathrm{mg} / \mathrm{kg}$ in feathers of birds can lead to adverse effects (Burger \& Gochfeld 2000, Grúz et al. 2018) and also can affect the development of the foetus and reproductive failure in mallards (Kertész \& Fáncsi 2003). Some of the sublethal effects of $\mathrm{Cr}$ in birds include retarded growth, anaemia and male gonad damage which might also claim the life of an organism (US Fish \& Wildlife Service 1986).

The mean concentration of chromium $(\mathrm{Cr})$ was reported to be $0.994 \mu \mathrm{g} / \mathrm{g}$ and Indian Eagle Owl (Bubo bengalensis) recorded the highest concentration of $\mathrm{Cr}$ content in kidneys $(2.56 \mu \mathrm{g} / \mathrm{g})$ followed by bone $(2.44 \mu \mathrm{g} / \mathrm{g})$, liver $(2.21 \mu \mathrm{g} / \mathrm{g})$ and muscle $(1.88 \mu \mathrm{g} / \mathrm{g})$ in comparison to Spotted Owlet and Barn Owl. Spotted Owlet (Athene brama) recorded 0.49 $\mu \mathrm{g} / \mathrm{g}$ in bone, followed by $0.44 \mu \mathrm{g} / \mathrm{g}$ in muscles, $0.41 \mu \mathrm{g} / \mathrm{g}$ in liver and $0.38 \mu \mathrm{g} / \mathrm{g}$ in kidney. The content of $\mathrm{Cr}$ recorded in Barn Owl was the lowest $(0.086-0.87 \mu \mathrm{g} / \mathrm{g})$ in its organs compared to the other two species of owls. In India, various studies have been carried out with respect to $\mathrm{Cr}$ in birds. Gaba \& Vashishat (2018) have reported $\mathrm{Cr}$ in the range of 3.52-12.05 $\mu \mathrm{g} / \mathrm{g}$ in excreta of Barn Owl and Spotted Owlet from Punjab, India. Another study by Kirubhanandhini et al. (2019) reported $\mathrm{Cr}$ concentrations in the range from 10.83$18.10 \mu \mathrm{g} / \mathrm{g}$ in muscle, liver and kidney tissues of Cattle Egret. Manjula et al. (2015) have reported an even higher level of $\mathrm{Cr}$ in Black Kite from Tiruchi, Chennai. However, the present study reported high levels of $\mathrm{Cr}$ compared to the study done by Grúz et al. (2018) who reported Cr in the range of $0.76 \pm 0.42 \mu \mathrm{g} / \mathrm{g}$ in owls (Long-eared Owl, Barn Owl and Tawny Owl) from Hungary. The present study was also in agreement with the findings of Deng et al. (2007) which reported $\mathrm{Cr}$ concentrations $(0.96 \pm 0.34 \mu \mathrm{g} / \mathrm{g})$ in liver tissues of Green Finch and $0.94 \pm 0.07 \mu \mathrm{g} / \mathrm{g}$ in the kidney of Green Finch and $0.69 \pm 0.06 \mu \mathrm{g} / \mathrm{g}$ in brain of the same. The present study also agreed with the findings of Boncompagni et al. (2003) who reported $0.94 \mu \mathrm{g} / \mathrm{g} \mathrm{Cr}$ in feathers of Little Egret from Karachi and $0.47 \mu \mathrm{g} / \mathrm{g} \mathrm{Cr}$ in feathers of Little Egret from Taunsa, Pakistan.

Lead: Grúz et al. (2018) stated that lead has the tendency to accumulate in calcium-rich tissues, bones, feathers and hair (Metcheva et al. 2006) and is not degradable. Studies by Burger et al. (1993) suggest that lead level above $4 \mathrm{mg} /$ $\mathrm{kg}$ leads to reproductive failure and feeding behaviour in species like gulls. Lead affects the well-being of an organism directly by influencing procreation, circulatory and nervous systems (Gochfeld 2000, US Fish \& Wildlife Service 1986, Kirubhanandhini et al 2019). However, Beyer et al. (1988) stated that symptoms of lead poisoning in birds vary among species.

The average concentration of lead recorded in the present study was $0.58 \pm 0.05 \mu \mathrm{g} / \mathrm{g}$ and Spotted Owlet (Athene brama) recorded the highest $\mathrm{Pb}$ content $(0.13 \mu \mathrm{g} / \mathrm{g})$ in bone followed by kidney $(0.12 \mu \mathrm{g} / \mathrm{g})$ and liver $(0.11) \mu \mathrm{g} / \mathrm{g}$. Compared to this, Indian Eagle Owl (Bubo bengalensis) recorded 0.16 $\mu \mathrm{g} / \mathrm{g}$ in kidney and $0.11 \mu \mathrm{g} / \mathrm{g}$ in bone. The level of $\mathrm{Pb}$ in Barn Owl (Tyto alba) was found comparatively much lower (0.007-0.034) $\mu \mathrm{g} / \mathrm{g}$ compared to the other two species. Studies carried out by Gaba \& Vashishat (2018) on heavy metal content in excreta of Barn Owl and Spotted Owlet from Punjab district depicted quite high and alarming levels of lead $(\mathrm{Pb}) 25.91 \mu \mathrm{g} / \mathrm{g}$ which was under the toxic range and above the normal range as stated by the authors. Grúz et al. (2018) from Hungary have reported $\mathrm{Pb}$ in owls (Long-eared Owl, Tawny Owl and Barn Owl) in the range from 1.71-2.47 $\mu \mathrm{g} / \mathrm{g}$. In a similar study done by Kim \& Koo (2007) in Korea in Eagle Owl, Brown Hawk Owl and Collared Scoops Owl has reported $\mathrm{Pb}$ in the range of 1.64-5.06 $\mu \mathrm{g} / \mathrm{g}$ respectively. Whereas in a study done by Nighat et al. (2013) in Indian Eagle Owl (Bubo bengalensis), $\mathrm{Pb}$ was reported to be 17.9 $\mu \mathrm{g} / \mathrm{g}$, and in Spotted Owlet (Athene brama) to be $6.44 \mu \mathrm{g} / \mathrm{g}$. Denneman \& Douben (1993) reported quite high concentration $(170 \mu \mathrm{g} / \mathrm{g})$ of $\mathrm{Pb}$ in primary feathers of Barn Owls from Netherlands. However, the findings of the present study were in agreement with the levels of lead $(\mathrm{Pb})$ reported by Kirubhanandhini et al. (2019) in muscles of Cattle Egret $(0.28 \mu \mathrm{g} / \mathrm{g})$, and with Gushit et al. (2016) in Red Cheeked Cordon Blue tail feathers $(0.28 \mu \mathrm{g} / \mathrm{g})$. When compared to similar investigations outside India, the present findings 
agreed with that of Deng et al. (2007) $(0.45 \pm 0.06 \mu \mathrm{g} / \mathrm{g})$ in Greenfinch liver and $(0.27 \pm 0.06 \mu \mathrm{g} / \mathrm{g})$ in Greenfinch brain and with that of Battaglia et al. (2005) who reported 0.35 $\mu \mathrm{g} / \mathrm{g} \mathrm{Pb}$ in liver, $0.50 \mu \mathrm{g} / \mathrm{g}$ in kidney, $0.88 \mu \mathrm{g} / \mathrm{g}$ in bone, and $0.10 \mu \mathrm{g} / \mathrm{g}$ in muscles. As the literature suggests, the $\mathrm{Pb}$ levels in the present findings were below the levels capable of imparting toxicity.

\section{CONCLUSION}

As the results suggest, the $\mathrm{Zn}, \mathrm{Pb}$ and $\mathrm{Cr}$ reported in the present study were at background levels which have been established for birds in the wild, and were definitely below the concentration of metals capable of imparting toxicity. However, differences in the concentration of heavy metal among the three species of owls throw light on the fact that environmental contamination is taking place in the environment which is inhabited by these owls. Differences in the metal contents among the 3 species of owls might have resulted due to differences in feeding habits and the availability of food resources based on the type of environment. A detailed study on their feeding guilds might be sufficient enough to provide further details in determining the source of environmental pollutants. Based on the results, it is unlikely to conclude that the extent of metal contamination threatens the life of the birds. However, owing to the fact that Visakhapatnam has many industries including petroleum industry, the presence of heavy metals in the environment is thus eminent (Biswas et al. 2019). Besides this, the presence of the heavy metals in the tissues of wild birds can also be contributed to the various point and non-point sources of pollution, which can be either natural or anthropogenic in origin and might continue to multiply through food chain leading to biomagnification.

\section{ACKNOWLEDGEMENT}

The authors are thankful to GITAM (Deemed to be University) for providing the necessary facilities. The first author is also thankful to University Grants Commission (UGC) for providing Rajiv Gandhi National Fellowship which funded the present study. The first author also extends thanks to Bay of Bengal Lab, Andhra University, Visakhapatnam for analysis of samples.

\section{REFERENCES}

Adrian, W. J. and Stevens, M. L. 1979. Wet versus dry weights for heavy metal toxicity determinations in duck liver. Journal of Wildlife Diseases, 15(1): 125-126.

Battaglia, A., Ghidini, S., Campanini, G. and Spaggiari, R. 2005. Heavy metal contamination in little owl (Athene noctua) and common buzzard (Buteo buteo) from northern Italy. Ecotoxicology and Environmental Safety, 60(1): 61-66.
Beyer, W. N., Spann, J. W., Sileo, L. and Franson, J. C. 1988. Lead poisoning in six captive avian species. Archives of Environmental Contamination and Toxicology, 17(1): 121-130.

Biswas, S., Ramakrishna, Ch and Maruthi, Y. A. 2019. Concentration of arsenic, lead, nickel in house crows (Corvus splendens) of Visakhapatnam city. Proceedings of the Zoological Society of India, 18(1): 59-64.

Boncompagni, E., Muhammad, A., Jabeen, R., Orvini, E., Gandini, C., Sanpera, C., Ruiz, X. and Fasola, M. 2003. Egrets as monitors of trace-metal contamination in wetlands of Pakistan. Arch. Environ. Contam. Toxicol., 45(3): 399-406.

Burger, J. and Gochfeld, M. 1993. Lead and cadmium accumulation in eggs and fledgling seabirds in the New York Bight. Environmental Toxicology and Chemistry, 12(2): 261-267.

Burger, J. and Gochfeld, M. 2000. Metal levels in feathers of 12 species of seabirds from Midway Atoll in the northern Pacific Ocean. Science of the Total Environment, 257(1): 37-52.

Dauwe, T., Janssen, E., Kempenaers, B. and Eens, M. 2004. The effect of heavy metal exposure on egg size, eggshell thickness and the number of spermatozoa in blue tit Parus caeruleus eggs. Environmental Pollution, 129(1): 125-129.

De Luca-Abbott, S. B., Wong, B. S., Peakall, D. B., Lam, P. K., Young, L., Lam, M. H. and Richardson, B. J. 2001. Review of effects of water pollution on the breeding success of waterbirds, with particular reference to ardeids in Hong Kong. Ecotoxicology, 10(6): 327-349.

Deng, J., Liao, B., Ye, M., Deng, D., Lan, C. and Shu, W. 2007. The effects of heavy metal pollution on genetic diversity in zinc/cadmium hyper accumulator Sedum alfredii populations. Plant and Soil, 297(1-2): 83-92.

Denneman, W.D. and Douben, P.E.T. 1993. Trace metals in primary feathers of the barn owl (Tyto alba guttatus) in the Netherlands. Environ. Pollution, 82(3): 301-310.

Furness, R.W. 1996. Cadmium in Birds. Environmental Contaminants in Wildlife: Interpreting Tissue Concentrations. Lewis, Boca Raton, 389-404.

Gaba, Y. and Vashishat, N. 2018. Estimation of heavy metal residues in excreta of spotted owlet (Athene brama) and barn owl (Tyto alba) from agro ecosystems of Punjab. Journal of Entomology and Zoology Studies, 6(3): 525-529.

Gochfeld, J. B. M. 2000. Effects of lead on birds (Laridae): A review of laboratory and field studies. Journal of Toxicology and Environmental Health, Part B: Critical Reviews, 3(2): 59-78.

Gragnaniello, S., Fulgione, D., Milone, M., Soppelsa, O., Cacace, P. and Ferrara, L. 2001. Sparrows as possible heavy-metal biomonitors of polluted environments. Bulletin of Environmental Contamination and Toxicology, 66(6): 719-726.

Grúz, A., Déri, J., Szemerédy, G., Szabó, K., Kormos, É., Bartha, A. and Budai, P. 2018. Monitoring of heavy metal burden in wild birds at eastern/ north-eastern part of Hungary. Environmental Science and Pollution Research, 25(7): 6378-6386.

Guitart, R., Sachana, M., Caloni, F., Croubels, S., Vandenbroucke, V. and Berny, P. 2010. Animal poisoning in Europe. Part 3: wildlife. The Veterinary Journal, 183(3): 260-265.

Gushit, J.S., Turshak, L.G., Chaskda, A.A., Abba, B.R. and Nwaeze, U.P. 2016. Avian feathers as bioindicator of heavy metal pollution in urban degraded woodland. Ewemen Journal of Analytical \& Environmental Chemistry, 2(2): 84-88.

IUCN 2019. www.iucnredlist.org

Janssen, C. R. and Heijerick, D. G. 2003. Algal toxicity tests for environmental risk assessments of metals. In: Reviews of Environmental Contamination and Toxicology, pp. 23-52.

Jayakumar, R. and Muralidharan, S. 2011. Metal contamination in select species of birds in Nilgiris District, Tamil Nadu, India. Bull. Environ. Contam. Toxicol., 87: 166-170.

Kaur, T. K., Vashishat, N. and Manoj, K. 2014. Heavy metal contamination in excreta of avian species from Ludhiana district of Punjab. International Journal of Advanced Research, 2(7): 873-879. 
Kertész, V. and Fáncsi, T. 2003. Adverse effects of (surface water pollutants) $\mathrm{Cd}, \mathrm{Cr}$ and $\mathrm{Pb}$ on the embryogenesis of the mallard. Aquat. Toxicol., 65(4): 425-433.

Kim, J. and Koo, T.H. 2007. Heavy metal concentrations in diet and livers of black-crowned night heron Nycticorax Nycticorax and grey heron Ardea Cinerea Chicks from Pyeongtaek, Korea. Ecotoxicology, 16(5): 411-416.

Kirubhanandhini, V., Muralidharan, S., Ganesan, K. and Shashikant, S.J. 2019. Elemental contamination in various species of birds from select states in India. Asian Journal of Engineering and Applied Technology, 8(2): 45-49.

Kushwaha, S. 2016. Heavy metal concentrations in feathers of critically endangered long-billed vultures (Gyps indicus) in Bundelkhand Region, India. International Journal of Life Sciences and Scientific Research, 2(4): 365-375.

Malik, R. N. and Zeb, N. 2009. Assessment of environmental contamination using feathers of Bubulcus ibis as a biomonitor of heavy metal pollution, Pakistan. Ecotoxicology, 18(5): 522-536.

Manjula, M., Mohanraj, R. and Devi, M. P. 2015. Biomonitoring of heavy metals in feathers of eleven common bird species in urban and rural environments of Tiruchirappalli, India. Environmental Monitoring and Assessment, 187(5): 267.

Metcheva, R., Yurukova, L., Teodorova, S. and Nikolova, E. 2006. The penguin feathers as bioindicator of Antarctica environmental state. Sci. Total Environ., 362(1-3): 259-265.

Mochizuki, M., Hondo, R. and Ueda, F. 2002. Simultaneous analysis for multiple heavy metals in contaminated biological samples. Biological Trace Element Research, 87(1-3): 211-223.
Muralidharan, S., Jayakumar, R. and Vishnu, G. 2004. Heavy metals in feathers of six species of birds in the District Nilgiris, India. Bulletin of Environmental Contamination and Toxicology, 73(2): 285-291.

Mustafa, I., Ghani, A., Arif, N., Asif, S., Khan, M. R., Waqas, A. and Malik, I. U. 2015. Comparative metal profiles in different organs of house sparrow (Passer domesticus) and black kite (Milvus migrans) in Sargodha District, Punjab, Pakistan. Pakistan Journal of Zoology, 47(4).

Nighat, S., Iqbal, S., Nadeem, M.S., Mahmood, T. and Shah, S.I. 2013. Estimation of heavy metal residues from the feathers of Falconidae, Accipitridae, and Strigidae in Punjab, Pakistan. Turk. J. Zool., 37: 488-500.

Outridge, P.M. and Scheuhammer, A.M. 1993. Bioaccumulation and toxicology of chromium: Implications for wildlife. Rev. Environ. Contam. Toxicol., 130: 31-77.

Sanchari, B., Ramakrishna, C.H. and Maruthi, Y.A. 2016. Extent of heavy metal accumulation in house crows of coastal zone. Life Sciences International Research Journal, 3(2): 158-161.

Sharma, C. and Vashishat, N. 2017. Assessment of heavy metals in excreta of house crow (Corvus splendens) from different agroecosystems of Ludhiana. Journal of Entomology and Zoology Studies, 5(4): 1891-1895.

Ullah, K., Hashmi, M. Z. and Malik, R.N. 2014. Heavy-metal levels in feathers of cattle egret and their surrounding environment: A case of the Punjab Province, Pakistan. Archives of Environmental Contamination and Toxicology, 66(1): 139-153.

US Fish and Wildlife Service. 1986. Chromium Hazards to Fish, Wildlife, and Invertebrates: A Synoptic Review. (Biological Report). Washington, USA: R. Eisler. 